\title{
Pemberdayaan Masyarakat Non Produktif Dusun Demangan Kabupaten Sukoharjo Melalui UMKM Berbasis Bahan Dasar Bekatul untuk Mewujudkan Ketahanan Ekonomi
}

\author{
Sajidan $^{\text {**, Fadhil Purnama Adi }}{ }^{2}$, Idam Ragil Widianto Atmojo ${ }^{3}$, Roy Ardiansyah4, \\ Dwi Yuniasih Saputri ${ }^{5}$ iD \\ 1,2,3,4,5 Universitas Sebelas Maret, Indonesia \\ *Corresponding author: sajidan898@gmail.com
}

\begin{abstract}
Abstrak
Penelitian ditujukan untuk memberikan pelatihan dan pengembangan usaha masyarakat non produktif melalui UMKM berbasis bahan dasar bekatul. Kegiatan pengabdian yaitu pemberian materi tentang kandungan bekatul, cara pengolahan bekatul sebagai pakan ternak berkualitas dan makanan bergizi, pengemasan dan pemasaran produk. Jumlah peserta yang diikutsertakan dalam program ini yakni sebanyak 35 masyarakat dengan teknik pengumpulan data penelitian dengan cara: observasi potensi, wawancara, analisis data sekunder, dan dokumentasi. Metode kegiatan pengabdian dilakukan dengan cara pemaparan materi oleh ahli, fact finding (analisis kebutuhan), discussion (diskusi antara pemateri), asking and answering (tanya jawab dan diskusi), dan recitation (resitasi atau pembagian tugas), practice and experiment (praktik dan eksperimen). Hasil kegiatan ini berupa temuan bahwa saat ini masyarakat memiliki pemahaman pengolahan bekatul terbatas pada produk olahan untuk pakan ternak. Kegiatan diskusi memberikan paradigma baru terhadap masyarakat untuk mengolah berbagai macam produk makanan berbahan bekatul. Pelatihan ini memberikan bekal kepada masyarakat untuk menganalisis produk berbahan bekatul untuk dikembangkan menjadi produk olahan makanan sehingga memiliki nilai jual yang lebih tinggi. Kegiatan pengabdian membekali masyarakat untuk memiliki pengetahuan dasar pengolahan makanan hingga ke tahap pemasaran sehingga diharapkan dapat meningkatkan perekonomian masyarakat.
\end{abstract}

Kata Kunci: Pengabdian, Dusun Demangun, Usaha, Bekatul

\section{Abstract}

The research is aimed at providing training and business development for non-productive communities through MSMEs based on rice bran. Service activities are providing material about the content of bran, how to process bran as quality animal feed and nutritious food, packaging and marketing of products. The number of participants included in this program is 35 people with research data collection techniques by means of: potential observation, interviews, secondary data analysis, and documentation. The method of service activities is carried out by presenting material by experts, fact finding (needs analysis), discussion (discussion between presenters), asking and answering (questions and answers and discussions), and recitation (recitation or division of tasks), practice and experiment (practice and experiment). The results of this activity are findings that currently people have limited understanding of rice bran processing to processed products for animal feed. Discussion activities provide a new paradigm for the community to process various kinds of food products made from rice bran. This training provides provisions for the community to analyze products made from rice bran to be developed into processed food products so that they have a higher selling value. Service activities equip the community to have basic knowledge of food processing to the marketing stage so that it is expected to improve the community's economy.

Keywords: Devotion, Demangun Hamlet, Business, Bekatul

\section{INTRODUCTION}

Bekatul adalah produk sampingan pengolahan beras yang menyumbang berton-ton limbah makanan per tahun, yang terdiri dari banyak nutrisi dan zat bioaktif yang mampu menurunkan risiko penyakit kronis tidak menular (Sonia Cozzano Ferreira et al., 2018).

$\begin{array}{ll}\text { History: } & \\ \text { Received } & \text { : April 02, } 2021 \\ \text { Revised } & \text { : April 09, } 2021 \\ \text { Accepted } & \text { : May 13, } 2021 \\ \text { Published } & \text { : May 25, } 2021\end{array}$


Industri pengolahan bekatul menjadi produk yang dapat dimakan sedang diminati karena melimpahnya bekatul sebagai produk sampingan di industri penggilingan padi dan pengenalan potensi komersialnya (Anderson \& Guraya, 2001). Bekatul sebagai produk sampingan dari proses pengggilingan padi mempunyai potensi besar dan dapat dijadikan sebagai peluang usaha yang menjanjikan apabila pemanfaatannya dapat dilakukan secara maksimal dan berkelanjutan. Bekatul merupakan hasil penyosohan kedua pada padi (Spaggiari et al., 2021). Lapisan bekatul terdiri dari aleurone layer, seed coat, dan germ yang tinggi kandungan gizinya (Susanti et al., 2019). Bekatul mempunyai nilai gizi tinggi karena kaya akan Vitamin B15, Kalsium, Magnesium, Mangan, Mangan, Kalium, dan Seng. Nutrisi yang terkandung didalam bekatul berupa protein, karbohidrat, serat dan berbagai vitamin, senyawa fenolik dan mineral menjadikan bekatul berpotensi sebagai pangan fungsional (Amagliani et al., 2017; Luthfianto et al., 2017). Dedak beras adalah sumber yang kaya vitamin, mineral, asam lemak esensial, serat makanan dan sterol lainnya (Gul et al., 2015).

Kandungan gizi yang terdapat pada bekatul tidak hanya dapat dijadikan sebagai pakan ternak tetapi juga dapat dimanfaatkan sebagai bahan pangan manusia yang bernilai gizi (Faizah et al., 2020). Bekatul juga mengandung protein, mineral, dan lemak tak jenuh, dan vitamin tinggi yang dibutuhkan pada aktifitas metabolisme sel tubuh manusia (Auliana, 2019). Manfaat bekatul bagi kesehatan yaitu berperan dalam pertumbuhan tulang dan gigi, mengatasi sembelit, memelihara pertumbuhan jaringan, menghambat kencing manis dan mencegah penyakit jantung (Susanti et al., 2019). Dedak padi mengandung 14-16\% protein kasar, dimana 3-4\% adalah lisin (Shih et al., 1999), dan oleh karena itu mengandung nilai gizinya tinggi (Sheflin et al., 2015).

Bekatul mempunyai nilai PER (protein efficiency ratio) sebesar 1,6-1,9 dimana PET pada kasien (standar) adalah 2,5. Karbohidrat utama di dalam bekatul padi adalah hemiselulosa $(8,7-11,4 \%)$, selulosa $(9-12,8 \%)$, pati (5-15\%) dan b-glucan (1\%). Bekatul secara umum mengandung; protein (11,5\%-17,2\%), lipid (10-23\%), karbohidrat mencapai $(51,1 \%-55 \%)$, abu (8\%-17,7\%), serat kasar (6,2\%-31,5\%), mineral, dan vitamin (Özgül Özdestan et al, 2014; Chinma et al., 2015; Huang \& Lai, 2016). Pemanfaatan bekatul sebagai bahan pangan mempunyai keunggulan tersendiri diantaranya membantu pencegahan penyakit kanker (Pham et al., 2017), jantung koroner, kegemukan, diabetes, berbagai masalah pencernaan, menurunkan kadar risiko penyakit kronis tidak menular (PTM) (Spiker et al., 2017), efektif untuk mengontrol berat badan dan faktor peradangan (Edrisi et al., 2018; Macagnan et al., 2016).

Namun, pemanfaatan potensi kelimpahan bekatul sebagai produk sampingan yang unggul belum dapat dimanfaatkan oleh masyarakat secara maksimal (Auliana, 2018). Masyarakat hanya memanfaatkan bekatul secara konvensional yaitu sebagai bahan campuran pakan ternak sehingga potensi ini tidak maksimal untuk dikelola sebagai unit usaha. Hal ini diakibatkan oleh kurangnya pengetahuan masyarakat untuk mengolah bekatul menjadi produk yang bernilai gizi. Mayoritas petani yang ada di masyarakat Dusun Demangan juga merupakan petani tradisional, sedangkan mayoritas masyarakat lainnya adalah buruh atau serabutan (tidak mempunyai pekerjaan tetap) sehingga tingkat kesejahteraan masyarakat masih kurang baik. Iklim berwirausaha yang ada di Dusun Demangan juga belum tampak. Hal ini dibuktikan dengan tidak adanya fasilitas berwirausaha seperti Unit Usaha Kecil dan Menengah (UMKM) yang dikelola secara mandiri. Berdasarkan beberapa masalah tersebut, masyarakat di Dusun Demangan dapat dikatakan sebagai masyarakat non produktif. Fakta tersebut akan berdampak pada tidak terfasilitasinya potensi usaha yang ada dan pengaruhnya terhadap tingkat kesejahteraan masyarakat Dusun Demangan. Untuk mengatasi permasalahan tersebut maka dibutuhkan suatu kegiatan pemberdayaan masyarakat berbasis UMKM yang dapat meningkatkan pemahaman serta produktifitas masyarakat dalam mengolah Bekatul. Kegiatan pemberdayaan melalui pembentukan UMKM juga dapat meningkatkan jumlah 
pengasilan serta kesejahteraan masyarakat Dusun Demangan. Pendirian UMKM ditujukan agar dapat membuka lapangan kerja baru dan meningkatkan kesejahterasaan masyarakat (Sedyastuti, 2018).

Dusun Demangan memiliki potensi yang sangat besar untuk mendirikan UMKM yang berbasis bahan Bekatul, hal ini dikarenakan berdasarkan hasil observasi yang dilakukan oleh tim pengabdian pada Desember 2020 hingga Januari 2021 menunjukkan bahwa Dusun Demangan memiliki kelimpahan produksi padi sebagai produk utama dan bekatul sebagai produk sampingan. Hal ini disebabkan oleh luasnya lahan pertanian dan sebagian masyarakat yang bermata pencaharian sebagai petani padi. Potensi Dusun Demangan sebagai unit usaha juga didukung oleh adanya fasilitas tempat penggilingan padi (selepan) yang memproduksi beras sebagai produk utama, dan sekam, bekatul, serta menir sebagai produk sampingan. Sehingga didirikannya UMKM terintegrasi dan terfasilitasi oleh pemerintah desa yang dikelola oleh masyarakat sebagai wujud usaha ekonomi kreatif dengan memanfaatkan kelimpahan bekatul akan dapat memberikan dampak yang positif bagi masyarakat. Adapun tujuan dari pelaksanaan kegiatan pemberdayaan masyarakat non produktif Dusun Demangan Kabupaten Sukoharjo melalui UMKM berbasis bahan dasar bekatul adalah untuk mewujudkan ketahanan ekonomi serta meningkatkan produktifitas serta kemampuan masyarakat dalam mengolah bahan dasar bekatul.

\section{MATERIALS AND METHODS}

Kegiatan pemberdayaan masyarakat dalam program pengabdian kepada masyarakat ini dilaksanakan di Dusun Demangan, Kecamatan Baki, Kabupaten Sukoharjo, Surakarta pada tanggal 10 April 2021. Kegiatan ini diikuti oleh 35 orang yang terdiri dari 30 Masyarakat Non Produktif (Buruh Tani, Pekerja Serabutan, Ibu Rumah Tangga) dan 5 utusan dari perangkat dusun. Penelitian ini menggunakan metode deskriptif kualitatif, sehingga data yang disajikan bersifat apa adanya dan tanpa adanya manipulasi maupun perlakuan lain. Pengumpulan data dilakukan dengan menggunakan teknik observasi yakni dengan mengobservasi secara langsung potensi yang ada di Dusun Demangan; wawancara, digunakan untuk mengetahui permasalahan yang ada; analisis data sekunder, digunakan untuk menganalisis kandungan bekatul, gambaran dan potensi desa; dan dokumentasi. Kegiatan dilaksanakan secara luring dan menerapkan protokol kesehatan sesuai dengan anjuran pemerintah dengan cara menggunakan masker dan menjaga jarak. Kegiatan pengabdian dilakukan dengan melakukan pendekatan kolaboratif dimana perencanaan metode dan waktu pelaksanaan pelatihan didiskusikan bersama dengan pihak mitra. Metode dalam pengabdian dilakukan dengan cara pemaparan materi oleh ahli, fact finding (analisis kebutuhan), discussion (diskusi antara pemateri), asking and answering (tanya jawab dan diskusi), dan recitation (resitasi atau pembagian tugas), practice and experiment (praktik dan eksperimen).

\section{RESULTS AND DISCUSSION}

\section{Hasil}

Prosedur kerja dalam program pengabdian kepada masyrakat ini dilakukan secara sistematis dan dimulai dari tahap fact finding (analisis kebutuhan), discussion (diskusi antara pemateri), asking and answering (tanya jawab dan diskusi), dan recitation (resitasi atau pembagian tugas), practice and experiment (praktik dan eksperimen). Adapun hasil yang ditunjukkan pada setia tahap pelaksanaan program adalah sebagai berikut: pada tahap pertama, yakni tahap analisis kebutuhan (fact finding) didapatkan hasil bahwa 96\% responden menyatakan belum mengetahui secara detail mengenai proses pengolahan serta 
pemanfaatan bekatul, sehingga pemanfaatan bahan dasar bekatul di Dusun Demangan masih sangat kurang. Selain dipengaruhi oleh ketidakmampuan masyarakat dalam mengolah bekatul, kurangnya pemanfaatan bekatul di Dusun Demangan juga disebabkan oleh luas lahan yang masih terbatas, jumlah hasil produksi masih rendah, waktu panen padi yang tidak menentuk, menjual dalam bentuk bahan mentah bahkan tidak digunakan, serta tidak adanya pengelolaan produk menjadi barang yang memiliki nilai jual tinggi. Sehingga berdasarkan analisis kebutuhan serta hasil analisis kuisioner, observasi serta wawancara dapat ditarik kesimpulan bahwa masyarakat desa bakipandeyan memerlukan pelatihan dalam pengelolaan optimalisasi bekatul dengan memberdayakan masyarakat non produktif menjadi socioprenuer berbasis ekonomi kreatif.

Tahap kedua yakni tahap discussion. Tahap discussion dilakukan setelah narasumber memaparkan materi mengenai proses pengolahan bahan dasar bekatul. Proses diskusi antara pemateri dengan peserta dan antar peserta dilakukan untuk menyamakan persepsi dan pengetahuan awal sebagai modal dasar dalam kegiatan pelatihan. Hasil temuan dari kegiatan diskusi yakni diketahui bahwa masyarakat di Desa Bakipandeyan belum memiliki pengetahuan yang memadai mengenai cara pengolahan produk berbahan baku bekatul. Masyarakat masih berpandangan bahwa pengolahan bekatul hanya terbatas untuk pakan ternak. Hal tersebut disampaikan oleh beberapa responden ketika diskusi menyampaikan bahwa:

\begin{abstract}
"Selama ini kami hanya mengolah bekatul menjadi pakan ternak, belum pernah mengolah menjadi makanan untuk kita konsumsi" (DK/01/02/2021)

"Keterbatasan pengetahuan kami menjadikan kami hanya mengolah bekatul hanya untuk pakan ternak, belum ada ide untuk digunakan sebagai olahan makanan (KWT/01/02/2021)
\end{abstract}

Berdasarkan hasil diskusi serta pemaparan materi dari narasumber didapatkan informasi bahwa terdapat beberapa metode yang dapat digunakan untuk mengubah produk sampingan ini menjadi produk lain zat bermanfaat seperti senyawa bioaktif, bahan makanan atau alat bantu pengolahan makanan. Itu proses fisik (homogenisasi, penggilingan koloid) dan beberapa teknologi baru (microwave dan ultrasonik) digunakan untuk mengekstrak protein, bukan ekstraksi basa yang menyediakan hasil rendah dan mengkonsumsi banyak pelarut. Selanjutnya, enzimatis juga digunakan untuk membantu ekstraksi protein dan meningkatkan bio-fungsi dan sifat fungsionalnya (Phongthai et al., 2017). Dari kegiatan ini, peserta mendapatkan informasi untuk membuat atau menghasilkan ide baru untuk mengekstrak atau menghasilkan bahan protein inovatif lainnya dari beras dan / atau bahan nabati lainnya. Protein beras semakin banyak digunakan dalam makanan. Dengan adanya kegiatan diskusi memberikan wawasan kepada masyarakat untuk mengolah bekatul menjadi beberapa produk makanan seperti brownies, kopi, nugget,pempek, dan snack ringan lainnya.

Tahap ketiga, yakni tahap Ask and Answering (metode tanya jawab dan diskusi) yang digunakan untuk mengetahui sejauh mana peserta telah ikut berpartisipasi dan menegaskan kembali tentang materi yang disampaikan. Peserta secara antusias aktif melaksanaan kegiatan ini. Hal ini dibuktikan pada saat pemaparan materi, peserta mencatat materi dan juga menanyakan berbagai hal yang belum jelas kepada pemateri. Materi yang ditanyakan yaitu seputar masalah yang dialami masyarakat mengenai pembuatan pakan ternak dan pengolahan bekatul secara detail. Setelah tahap Ask and Answering selesai maka tahap pelaksaan program dilanjutkan pada tahap keempat, yakni tahap Recitation (pemberian tugas) yang digunakan untuk memberi kesempatan pada peserta untuk merencanakan dan mengimplementasikan pengembangan usaha berbahan dasar bekatul sesuai dengan arahan dan materi yang disampaikan sehingga tidak lagi hanya menjual produk bekatul mentah atau bahkan tidak 
digunakan. Pelaksanaan kegiatan dilakukan secara berkelompok agar dapat mengetahui tingkat pemahaman dan kesulitan yang dihadapi ketika merencanakan dan menyusun serta mengimplementasikan pengembangan usaha berbahan dasar bekatul, sehingga dapat dicari pemecahan masalah dari kesulitan yang dihadapi tersebut. Pengelompokkan dilakukan dengan tetap mempertimbangkan pembagian peserta yang menguasai materi dan teknologi dengan baik. Pada saat dibentuk kelompok, peserta melakukan diberikan waktu untuk diskusi untuk mempersiapkan pembagian tugas saat melakukan pelatihan.

Tahap yang terakhir yakni tahap Practice and Experiment. Tahap Practice and Experiment merupakan tahap yang mendominasi sekitar $80 \%$ dari pelatihan dan dilaksanakan dengan cara membuat produk berbahan dasar bektul serta merencanakan pola manajaemen usaha kemitraan rakyat. Kegiatan praktik dan eksperimen dalam pemberdayaan masyarakat non produktif diharapkan untuk membangun kesadarannya, mendorong, memotivasi, dan membangkitkan kesadaran yang dimilikinya untuk berupaya mengembangkannya. Hal tersebut didukung dengan hasil pelatihan yang dilakukan tentang pelatihan pemanfaatan dedak padi/ rice bran sebagai bahan tambahan pangan dan produk perawatan tubuh bagi masyarakat yang dapat meningkatkan kemandirian ekonomi dan kesejahteraan masyarakat (Sari et al., 2019). Berdasarkan analisis terhadap hasil penelitian didapatkan informasi bahwa bahan dasar bekatul di Desa Bakipandeyan belum dapat dimanfaatkan dengan baik, hal ini dikarenakan kurangnya kemampuan serta pengetahuan masyarakat mengenai cara pengolahan bahan dasar bekatul serta jumlah hasil produksi masih rendah, waktu panen padi yang tidak menentu, menjual dalam bentuk bahan mentah bahkan tidak digunakan, serta tidak adanya pengelolaan produk menjadi barang yang memiliki nilai jual tinggi. Rendahnya kemampuan masyarakat dalam mengolah bekatul tidak hanya terjadi di Desa Bakipandeyan saja, tetapi juga terjadi di berbagai wilayah di Indonesia yang cenderung memiliki ketersediaan bekatul yang cukup melimpah (Luthfianto et al., 2017).

Untuk mengatasi berbagai permasalahan yang ada serta memaksimalkan sumber daya bekatul di Desa Bakipandeyan maka masyarakat membutuhkan suatu pelatihan serta pembedayaan dalam hal mengolah bahan dasar bekatul. Pada dasarnya bekatul merupakan produk sampingan pengolahan beras yang menyumbang berton-ton limbah makanan per tahun, yang terdiri dari banyak nutrisi dan zat bioaktif yang mampu menurunkan risiko penyakit kronis tidak menular (Sonia Cozzano Ferreira et al., 2018). Bekatul dapat diolah menjadi berbagai macam makanan seperti oats, minyak bekatul, tepung bekatul, dll (Tuarita et al., 2017). Pemberdayaan masyarakat melalui pembentukan UMKM yang menghasilkan produk berbahan dasar bekatul akan dapat meningkatkan jumlah penghasilan masyarakat serta mengurangi limbah bekatul di lingkungan. Hal ini sejalan dengan beberapa hasil penelitian yang menunjukkan bahwa kegiatan pemberdayaan masyarakat melalui pembentukan UMKM efektif digunakan untuk memaksimalkan sumber daya yang ada di masyarakat (Syadzali, 2020; Yani et al., 2020).

\section{CONCLUSION}

Kegiatan pengabdian masyarakat untuk memberdayakan masyarakat non produktif di Dusun Demangun Kabupaten Sukoharjo diikuti oleh 35 orang yang terdiri dari 30 Masyarakat Non Produktif (Buruh Tani, Pekerja Serabutan, Ibu Rumah Tangga) dan 5 utusan dari perangkat desa. Kegiatan pengabdian masyarakat ini dilaksanakan dalam beberapa tahap, yakni dimulai dari tahap fact finding (analisis kebutuhan), discussion (diskusi antara pemateri), asking and answering (tanya jawab dan diskusi), dan recitation (resitasi atau pembagian tugas), practice and experiment (praktik dan eksperimen). Kegiatan pengabdian diterima dengan positif oleh masyarakat. Masyarakat yang ikut dalam kegiatan pengabdian juga sangat antusias dalam mengikuti kegiatan pengabdian. Hal ini dapat dibuktikan pada 
kegiatan pengabdian, masyarakat memperhatikan materi yang disampaikan saat pemaparan, menulis hal-hal penting terkait pemaparan materi, aktif bertanya ketika sesi tanya jawab, serta aktif dalam berdiskusi kelompok dan pelaksanaan pembuatan berbagai makanan dari bekatul. Saran yang diberikan dalam penelitian ini yaitu tim peneliti dapat menambahkan data yang lebih lengkap dan valid. Tim peneliti juga dapat menambah lebih banyak kegiatan pengabdian lain yang dapat membuat masyarakat lebih produktif sehingga mampu memaksimalkan ketahanan pangan masyarakat di tengah pandemi Covid-19 ini.

\section{REFERENCES}

Amagliani, L., O’Regan, J., Kelly, A. L., \& O’Mahony, J. A. (2017). Composition and protein profile analysis of rice protein ingredients. Journal of Food Composition and Analysis. https://doi.org/ 10.1016/j.jfca.2016.12.026.

Anderson, A. K., \& Guraya, H. S. (2001). Extractability of protein in physically processed rice bran. JAOCS, Journal of the American Oil Chemists' Society, 78(9), 969-972. https://doi.org/10.1007/s11746-001-0373-1.

Auliana, R. (2019). Pembuatan Tempe Bekatul Dan Kandungan Gizinya. Home Economics Journal, 1(2), 70-76. https://doi.org/10.21831/hej.v1i2.23288.

Auliana, R. (2018). Pemanfaatan Bekatul Sebagai Sumber Ide Dalam Pembelajaran Patiseri Diet. Prosiding Pendidikan Teknik Boga Busana, 3(2). https://journal.uny.ac.id/index.php/ptbb/article/view/ 33669/14080.

Chinma, C. E., Ramakrishnan, Y., Ilowefah, M., Hanis-Syazwani, M., \& Muhammad, K. (2015). Properties of cereal brans: A review. Cereal Chemistry. https://doi.org/10.1094/CCHEM-10-13-0221-RW.

Edrisi, F., Salehi, M., Ahmadi, A., Fararoei, M., Rusta, F., \& Mahmoodianfard, S. (2018). Effects of supplementation with rice husk powder and rice bran on inflammatory factors in overweight and obese adults following an energy-restricted diet: a randomized controlled trial. European Journal of Nutrition. https://doi.org/10.1007/s00394-017-1555-3.

Faizah, F., Kusnandar, F., \& Nurjanah, S. (2020). Senyawa Fenolik, Oryzanol, Dan Aktivitas Antioksidan Bekatul Yang Difermentasi Dengan Rhizopus oryzae. Jurnal Teknologi Dan Industri Pangan, 31(1), 86-94. https://doi.org/10.6066/jtip.2020.31.1.86.

Gul, K., Yousuf, B., Singh, A. K., Singh, P., \& Wani, A. A. (2015). Rice bran: Nutritional values and its emerging potential for development of functional food - A review. Bioactive Carbohydrates and Dietary Fibre, 6(1), 24-30. https://doi.org/10.1016/j.bcdf.2015.06.002.

Huang, Y. P., \& Lai, H. M. (2016). Bioactive compounds and antioxidative activity of colored rice bran. Journal of Food and Drug Analysis. https://doi.org/10.1016/j.jfda.2016.01.004.

Luthfianto, D., Noviyanti, R. D., \& Kurniawati, I. (2017). Karakterisasi Kandungan Zat Gizi Bekatul pada Berbagai Varietas Beras di Surakarta. Jurnal Kesehatan, 2(1), 371-376. https://journal.unimma. ac.id/index.php/urecol/article/view/1542.

Macagnan, F. T., da Silva, L. P., \& Hecktheuer, L. H. (2016). Dietary fibre: The scientific search for an ideal definition and methodology of analysis, and its physiological importance as a carrier of bioactive compounds. In Food Research International. https://doi.org/10.1016/j.foodres.2016.04.032.

Pham, T., Thomas Teoh, K., Savary, B. J., Chen, M. H., McClung, A., \& Lee, S. O. (2017). In vitro fermentation patterns of rice bran components by human gut microbiota. Nutrients. https://doi.org/10.3390/nu9111237.

Phongthai, S., Homthawornchoo, W., \& Rawdkuen, S. (2017). Preparation, properties and 
application of rice bran protein: A review. In International Food Research Journal.

Sari, F., Nugrahani, R. A., Susanty, Redjeki, A. S., \& Hendrawati, T. Y. (2019). Pelatihan Pemanfaatan Dedak Padi (Rice Bran) sebagai Bahan Tambahan Pangan dan Produk Perawatan Tubuh bagi Masyarakat. Prosiding Seminar Nasional Pengabdian $\begin{array}{llll}\text { Masyarakat } \quad \text { LPPM } & \text { UMJ, } & \text { https://jurnal.umj.ac.id }\end{array}$ /index.php/semnaskat/article/view/5401.

Sedyastuti, K. (2018). Analisis Pemberdayaan UMKM Dan Peningkatan Daya Saing Dalam Kancah Pasar Global. INOBIS: Jurnal Inovasi Bisnis Dan Manajemen Indonesia, 2(1), 117-127. https://doi.org/10.31842/jurnal-inobis.v2i1.65.

Sheflin, A. M., Borresen, E. C., Wdowik, M. J., Rao, S., Brown, R. J., Heuberger, A. L., Broeckling, C. D., Weir, T. L., \& Ryan, E. P. (2015). Pilot dietary intervention with heat-stabilized rice bran modulates stool microbiota and metabolites in healthy adults. Nutrients. https://doi.org/10.3390/nu7021282.

Shih, F. F., Champagne, E. T., Daigle, K., \& Zarins, Z. (1999). Use of enzymes in the processing of protein products from rice bran and rice flour. Nahrung - Food. https://doi.org/10.1002.

Sonia Cozzano Ferreira, Adriana Maite Fernandez, Marfa Dolores de Castillo Bilbao, \& Alejandra Medrano Fernandez. (2018). New functional ingredients from agroindustrial by-products for the development of healthy foods. In Encyclopedia of Food Security and Sustainability. https://doi.org/10.1016/B978-0-08-1005965.22140-9.

Spaggiari, M., Dall'asta, C., Galaverna, G., \& Bilbao, M. D. D. C. (2021). Rice bran byproduct: From valorization strategies to nutritional perspectives. In Foods. https://doi.org/10.3390/foods10010085.

Spiker, M. L., Hiza, H. A. B., Siddiqi, S. M., \& Neff, R. A. (2017). Wasted Food, Wasted Nutrients: Nutrient Loss from Wasted Food in the United States and Comparison to Gaps in Dietary Intake. Journal of the Academy of Nutrition and Dietetics. https://doi.org/10.1016/j.jand.2017.03.015.

Susanti, S., Arifan, F., \& Basit, N. (2019). Pemanfaatan Bekatul sebagai Sumber Serat Pangan Pensubstitusi Terigu pada Proses Pembuatan Brownies Kukus. Seminar Nasional Kolaborasi Pengabdian Kepada Masyarakat UNDIP-UNNES, 472-475. http://proceedings.undip.ac.id/index.php/semnasppm2019/ article/viewFile/212/179.

Syadzali, M. M. (2020). Model Pemberdayaan Masyarakat Melalui Pengembangan Ekonomi Lokal (Study Pada UKM Pembuat Kopi Muria). Syntax Idea, 2(5), 91. https://doi.org/10.36418/syntax-idea.v2i5.255.

Tuarita, M. Z., Sadek, N. F., Sukarno, Yuliana, N. D., \& Budijanto, S. (2017). Pengembangan Bekatul sebagai Pangan Fungsional: Peluang, Hambatan, dan Tantangan. Jurnal Pangan, 26(2), 167-176. https://doi.org/https://doi.org/10.33964/jp.v26i2.354.

Yani, A. S., Fauziah, F., Putra, R. J., \& Mila, M. (2020). Pemberdayaan Masyarakat Desa Cileuksa Dalam Meningkatkan Perekonomian Masyarakat Melalui UMKM. Jurnal Komunitas: Jurnal Pengabdian Kepada Masyarakat, 3(1), 1-5. https://doi.org/10.31334/jks.v3i1.962. 